It has, of course, long been known vaguely that the rootstock has some influence on the performance of a tree but the accumulated results of the Station's experiments have shown just what this influence may achieve and how advantage may be taken of it, though it is not yet clear what physiological and chemical mechanism is involved in the translation of rootstock potentialities into scion performance. It is, however, now certain that choice of rootstock may mean the difference between the economic success and failure of a plantation, since such factors as the vigour and disease-resistance of the tree, the age at which fruit-production begins, the amount of crop and the size, colour and quality of the fruit may all be affected by the rootstock.

Some control of these factors may, of course, be achieved by such cultural treatments as pruning and manuring, but since tree fruit plantations are planned in relation to a future of $30-50$ years, the importance of obtaining control of the trees by selecting at the outset the correct rootstock in relation to its purpose need scarcely be emphasised. The extent of this control is such that it is now possible by rootstock selection to choose in advance whether a tree shall become a dwarf bush for the garden or a large 'standard' with a spread of $40 \mathrm{ft}$., and in fact to produce at will trees suitable each for its particular purpose.

The natural corollary of these investigations was not only to make them known to the fruit. growing industry but also to make available the material with the aid of which the principles could be applied. Consequently in order to ensure that growers and nurserymen shall be able to procure in quantity suitable rootstocks and desirable and healthy varieties of small fruits all true to type, the Station has established a considerable acreage of nurseries where material is raised and distributed through commercial sources. The number of plants thus made available now amounts to 250,000 annually. The area now under experiments amounts to 130 acres and in the course of the investigations problems have arisen which have necessitated co-operation of pomologists, physiologists, mycologists, bacteriologists, entomologists, statisticians and chemists; their publications appear in the Station's Annual Reports and in biological journals, chiefly the Journal of Pomology and Horticultural Science.

The Imperial Bureau of Fruit Production, founded in 1929, is housed at the Station and acts as a clearing house of information concerning research on fruit plants, which is made available through Horticultural Abstracts.

\title{
Canadian Water Power Developments during 1933
}

\section{By Dr. Brysson Cunningham}

$\mathrm{T}$ $\mathrm{HE}$ recent issue by the Dominion Water Power and Hydrometric Bureau of the Canadian Department of the Interior of two reports $^{1}$ relating to hydro-electric developments during the year 1933 enables a fresh survey to be made of the remarkable progress which continues to be achieved in the Dominion in the exploitation of its natural water power resources.

It was scarcely to be expected that the rate of development which, from 1924 until the end of 1932, was fairly constant at the high figure of nearly 440,000 additional horse power per annum, could be maintained during the present period of economic depression. In the circumstances, it is satisfactory to record that the net increase during 1933 was no less than 270,210 horse power, bringing (with a previously untabled item of 16,600 horse power in 1932) the total development at the beginning of this year up to $7,332,070$. It is conservatively estimated that this represents a capital investment of $1,675,000,000$ dollars and that it is capable of effecting a saving of about $36,000,000$ tons of coal per annum. The actual saving for the year 1933 is computed at $14,775,000$ tons. As projects require several years to materialise, the annual increment of power is, of course, mainly due to installations the inception of which dates back a corresponding period. During 1934 and thereafter, there will be further increments on the completion of undertakings now under way, but, from the point of view of the maintenance of the rate of progress, it is significant and unfortunate that no undertakings of magnitude were initiated during 1933.

The distribution of the present realised total of $7,332,070$ horse power among the various provinces of the Dominion is shown in the accompanying

AVAILABLE AND DEVELOPED WATER POWER IN CANADA, January 1, 1934.

\begin{tabular}{|c|c|c|c|c|}
\hline \multirow{2}{*}{\multicolumn{2}{|c|}{ Province }} & \multicolumn{2}{|c|}{$\begin{array}{l}\text { Available } 24 \text {-hour power } \\
\text { at } 80 \text { per cent Efficiency }\end{array}$} & \multirow{2}{*}{$\begin{array}{l}\text { Turbine } \\
\text { Installation } \\
\text { (h.p.) }\end{array}$} \\
\hline & & $\begin{array}{l}\text { At Ordinary } \\
\text { Min. Flow } \\
\text { (h.p.) }\end{array}$ & $\begin{array}{l}\text { At Ordinary } \\
\text { Six Months } \\
\text { Flow (h.p.) }\end{array}$ & \\
\hline \multicolumn{2}{|c|}{ British Columbia ... } & $1,931,000$ & $5,103,500$ & 717,602 \\
\hline Alberta & & 390,000 & $1,049,500$ & 71,597 \\
\hline Saskatchewan & & 542,000 & $1,082,000$ & 42,035 \\
\hline Manitoba .. & .. & $3,309,000$ & $5,344,500$ & 390,925 \\
\hline Ontario $\quad .$. & $\because$ & $5,330,000$ & $6,940,000$ & $2,355,105$ \\
\hline Quebec & & $8,459,000$ & $13,064,000$ & $3,493,320$ \\
\hline New Brunswick & & 68,600 & 169,100 & 133,681 \\
\hline Nova Scotia & & 20,800 & 128,300 & 112,167 \\
\hline Prince Edward Isle & & 3,000 & 5,300 & 2,439 \\
\hline Yukon and Northu & west Terr. & 294,000 & 731,000 & 13,199 \\
\hline Total & $\ldots$ & $20,347,400$ & $33,617,200$ & $7,332,070$ \\
\hline
\end{tabular}

table, which also exhibits a statement of the estimated total power available. It would not be correct, however, to deduct the realised horse power in column 4 from either of the totals of available power in columns 2 and 3 , for the purpose of arriving at the balance still awaiting development, because experience in the matter of turbine 
installation demonstrates the realisation of an excess of some 30 per cent over the ordinary six months' flow power. On this basis, it is a legitimate conclusion that the recorded water power resources of the Dominion will permit of a turbine installation of about $43,700,000$ horse power, of which the present realised total is rather less than 17 per cent. Even so, the per capita development for the Dominion, namely, 686 horse power per 1,000 of the population, places Canada in an outstanding position among countries of the world using water power.

Of the 270,210 horse power brought into operation during 1933 , rather more than a moiety (136,000 horse power) is due to the completion of the Masson Development of the MacLarenQuebec Company, situated at the mouth of the Lievre River in Quebec Province, of which a view is given in Fig. 1. It comprises four turbine units, each of 34,000 horse power, and has a dam and intake 1,050 ft. long with a tunnel 6,060 ft. long leading to the power house. There is an effective head of $185 \mathrm{ft}$.

Another important enterprise, now in hand, is the Canyon Development on the Lower Abitibi

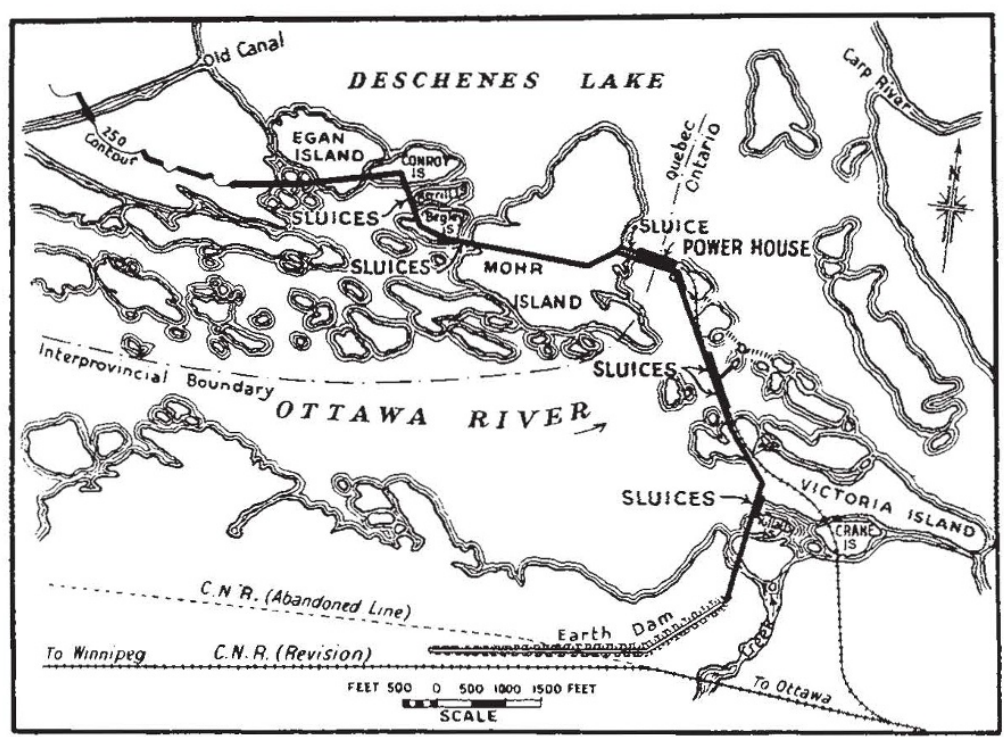

Fro. 2. Site plan of the Chats Falls Development.

River in Ontario, which has been acquired by the Provincial Government and its operation placed in the hands of the Hydro-electric Power Commission of Ontario. Ultimately, the installation will comprise five turbine units of 66,000 horse power each.
Two of these are complete and in operation, the first having been put into commission in May 1933 and the second in August last. A cable line at a voltage of 132,000 transmits current from the

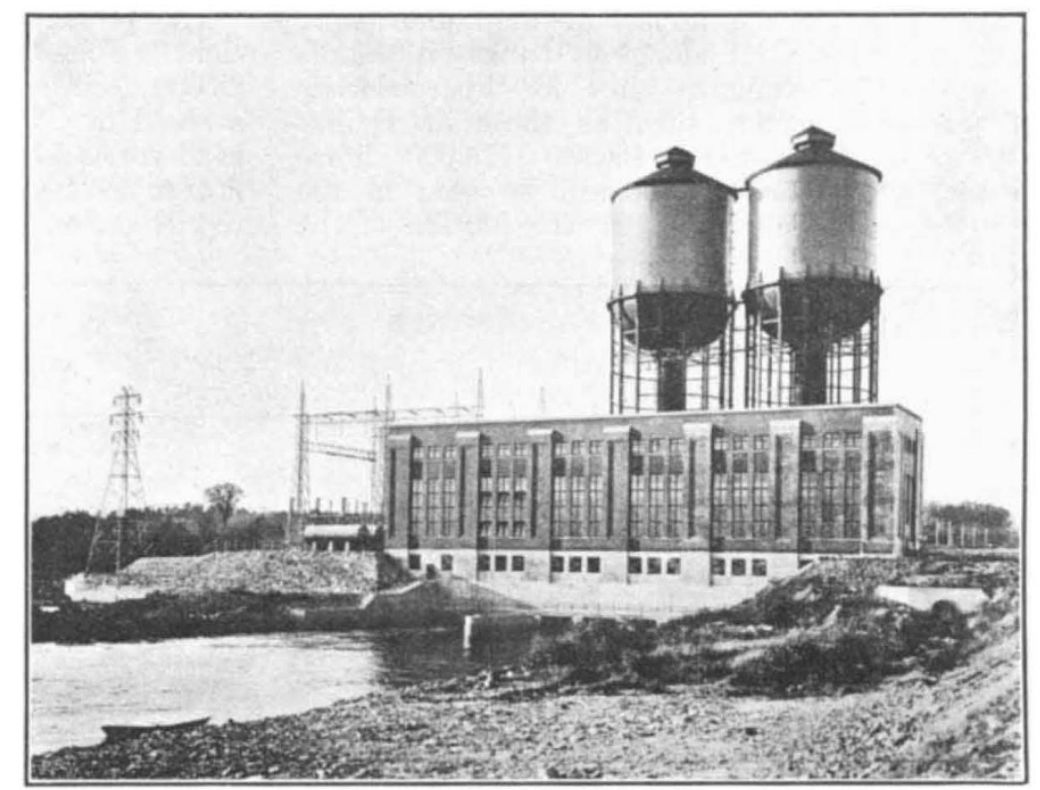
Fra. 1. Masson Development, Lievre River, Quebec, 136,000 h.p., of the MacLaren-Quebec
Power Company. By courtesy of the Dominion Water Power and Hydrometric Bureau, Ottawa.
Canyon to the Sudbury mining district, 246 miles distant. Under an agreement recently concluded between the Hydro-electric Power Commission and the Canadian Northern Power Corporation, current from the Canyon will be an important factor in mining development in Northern Ontario.

The Beauharnois installation, described in Nature of June 3, 1933, continues to expand. During 1933, contracts were placed for the balance of the equipment (turbines, generators, transformers and switching equipment) necessary to produce the full 500,000 horse power development, and this is expected to be realised in 1936. The present capacity is 133,000 horse power, exclusive of that required for constructional purposes.

Although not coming precisely within the limits of the period under review, the Chats Falls Development ${ }^{2}$, completed in September 1932, is an undertaking the magnitude of which merits some notice ; and, moreover, apart from its outstanding capacity of nearly a quarter of a million horse power, it is the first major power development in the inter-provincial section of the Ottawa River which constitutes a complete 
exploitation of the whole flow at any site. The Ottawa River is the boundary between the Provinces of Ontario and Quebec for a length of 300 miles from Lake Timiskaming to Carillon, a point 25 miles from the junction with the St. Lawrence. Favourably for the important pulp and paper factories established along its banks, it affords a number of valuable sites for hydro-electric power development, such as those at Quinze (40,000 horse power), Bryson $(25,000$ horse power) and Ottawa. As will be seen in the plan of the locality (Fig. 2), the portion of the
45,000 cusecs, with a dependable minimum of 22,000 cusecs, which by the enlargement of certain storage facilities on the main stream and its tributaries is susceptible of an increase to 28,000 cusecs.

The present hydraulic installation consists of eight turbines, each with a rated capacity of 28,000 horse power under a head of $53 \mathrm{ft}$. and at a speed of $125 \mathrm{rev}$. per minute. The operating head varies from $38 \mathrm{ft}$. at times of very high river flow to $58 \mathrm{ft}$. at low flows. The photographic view reproduced in Fig. 3, which has been courteously

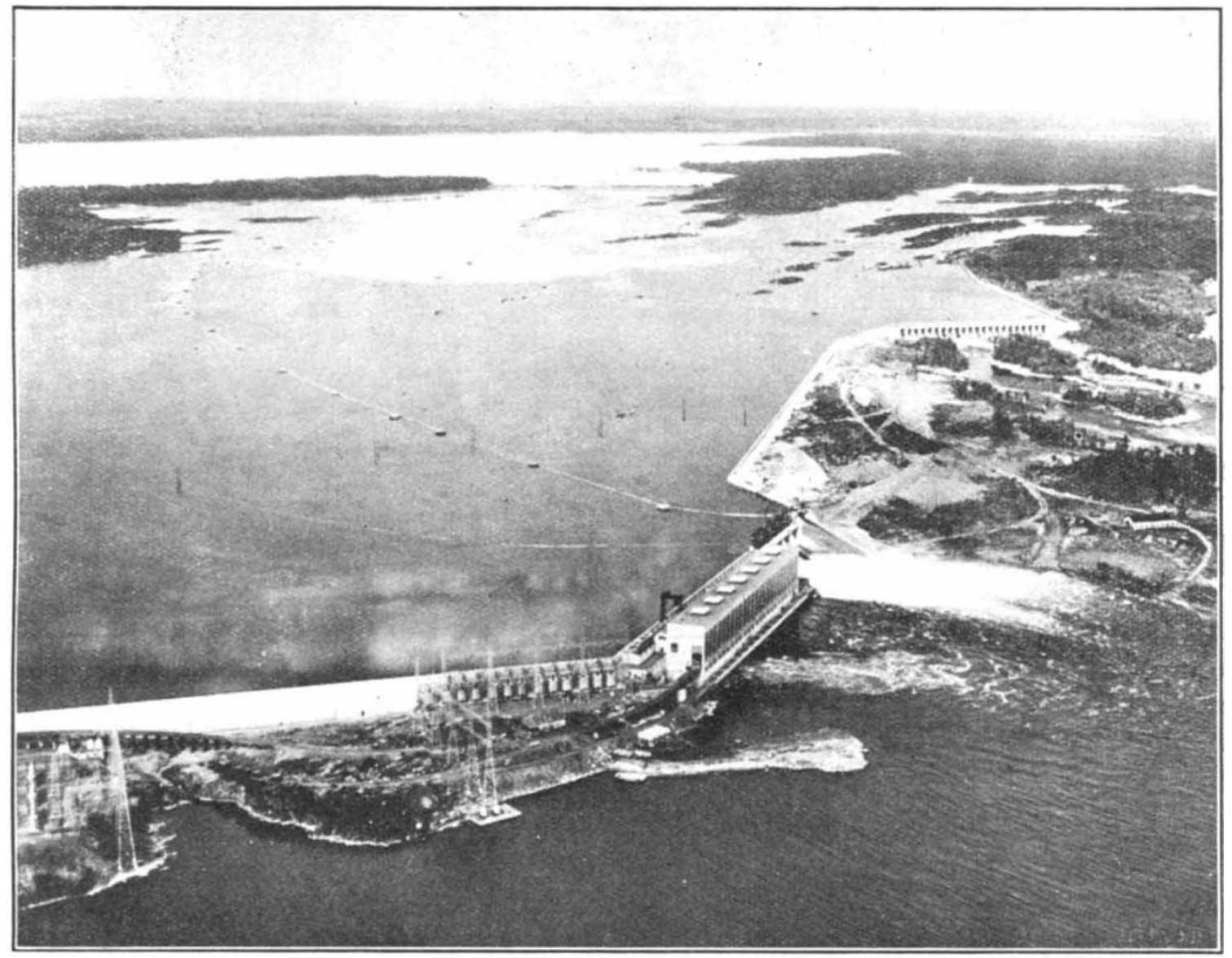

Fig. 3. Chats Falls Development, 224,000 h.p., of the Hydro-Electric Power Commission of Ontario and the Ottawa Valley Power Company. By courtesy of - the Chats Falls Engineering Board.

river developed at Chats Falls lies between Chats Lake and Lake Deschenes. These lakes are really broadened expanses of the river and they have areas of 27 and 36 square miles respectively. Uniting them is a channel about 3 miles in length, in which there is a natural fall of about $50 \mathrm{ft}$., $38 \mathrm{ft}$. of which are in the falls proper at the lower end of the channel, and the remainder in the rapids above the falls. The rapids and the falls are separated by a sheet of water, one square mile in area, known as the Fishery Pool, and this forms the forebay of the development. From records taken over a period of seventeen years, it has been ascertained that the mean flow at Chats Falls is supplied by Dr. Hogg, chairman of the Chats Falls Engineering Board, shows the power house and forebay with part of the adjacent constructional works, the latter being more completely indicated on the plan (Fig. 2). To the left of the power house (in the photograph), on the Ontario shore, there are, in turn, a gravity dam some $1,200 \mathrm{ft}$. in length ; 32 sluices, known as the Ragged Chute sluices, each with a clear opening of $18 \mathrm{ft}$. a gravity dam, 1,350 ft. long ; the Victoria sluices, 10 in number, also with $18 \mathrm{ft}$. openings, and a further gravity dam of 1,450 ft. length. Beyond this, there is a low earthen dyke, or embankment, parallel with the river edge, extending for nearly 
a mile upstream. On account of these works, a section of the Canadian Railway, two miles in length, had to be re-laid farther inshore. On the Quebec, or western side, immediately adjacent to the power house are 4 sluices, each $40 \mathrm{ft}$. in width, and a log slide ; then a gravity dam, 2,000 ft. long; the 10 Wolverine sluices; another dam, $650 \mathrm{ft}$. long; 22 Merrill Island sluices and, finally, a dam, $2,600 \mathrm{ft}$. long, terminating in a number of short disconnected lengths closing low-lying areas. Alongside the power house, in the foreground of Fig. 3, can be seen the transformer station, consisting of 13 single phase transformèrs, $13 \cdot 2 \mathrm{kv}$. to $220 \mathrm{kv}$., while $800 \mathrm{ft}$. farther along is the $220 \mathrm{kv}$. switching station occupying an area of about $300 \mathrm{ft}$. by $360 \mathrm{ft}$.

Not the least important feature of hydroelectrical exploitation on a national or provincial scale is the regulation of water supplies, and in this connexion the work of the Quebec Streams Commission is worthy of notice. The Commission continues to maintain with every success the desired regulation of flow on all the controlled rivers through its extensive system of storage reservoirs in various parts of the province. It controls seventeen reservoirs, five of which are on the St. Maurice River, two on the St. Francois River, two on the Gatineau River, one at Lake Kenogami for the Sable and Chicoutimi Rivers; three on the North River (Lakes Masson, Long and Bedini) ; two on the St. Anne de Beaupré River (Lakes Brulé and Savane); one on Mitis River and one on Rivière du Lievre. The Commission has also proceeded with the further investigation of storage problems on the Upper Ottawa River, including Jourdan Lake. Numerous lakes have been examined to determine whether they are to be considered as navigable waters, and river profiles have been taken. Studies of ice formation have been made and also sundry investigations of back water and drainage, besides the execution of bank protection work.

1 "Hydro-electric Progress in 1933". By the Hon. Thos. G. Murphy, Minister of the Interior, Ottawa. "Water Power Resources of Canada" Paper No. 1733. Dominion Water Power and Hydrometric Bureau, Ottawa.

2 The Chats Falls Development. Papers by various writers, reprinted from the Engineering Journal, Canada, February and March, 1933.

\section{World Climate during the Quaternary Period}

$\mathrm{A}^{\mathrm{T}}$ T the Royal Meteorological Society on May 16, Dr. G. C. Simpson read an important paper on his theory of the climatic variations during the Quaternary Ice Age, with especial reference to its geological implications. Briefly, the theory states that the effect of an increase in the solar radiation intercepted by the earth is a relatively small increase in the earth's temperature, but a large increase in the evaporation, cloudiness and precipitation. In high latitudes or on high mountains, where the precipitation is mainly in the form of snow, the first result is an extension of the icesheets and glaciers, but as the radiation increases still further, the rise of temperature becomes great enough to melt away the ice. If the solar radiation, starting from a minimum, goes through two complete cycles, the climatic succession would be : cold dry climate; glacial ; warm wet interglacial ; glacial ; cold dry interglacial ; glacial ; warm wet interglacial ; glacial ; cold dry climate. Hence there would be four glacial periods separated by three interglacials, of which only the first and third would actually be warm. In low latitudes, on the other hand, the two cycles of radiation would be represented only by two pluvial periods separated by an interpluvial, the maximum of each pluvial coinciding with a warm wet interglacial.

The physical basis of the theory offers no difficulty, requiring only that the earth shall fluctuate in the unstable zone between insufficient snowfall and too great heat. The real test is whether the theory fits the geological facts, and in his latest paper Dr. Simpson arrays an impressive mass of evidence that the fit is very good indeed. Two primary difficulties are first attacked; the centre of glaciation in the northern hemisphere was not the north pole, but lay somewhere in Greenland, while careful analysis by Penck and Brückner has shown that, in the Alps, glaciation was not due to increased snowfall but to decreased temperature. Both these difficulties are explained by the geographical fact that the North Atlantic is open to the Arctic, while the North Pacific is not. During the oncoming of a glacial period there was a great accumulation of floating ice in the Arctic Ocean, and the only outlet through which this could escape led into the Atlantic, which was covered by ice floes down to comparatively low latitudes, while the Pacific was ice-free. This floating ice greatly lowered the temperature of eastern North America and still more of western Europe, and led to the great extension of glaciation in countries bordering on the Atlantic. In the early stages of the Quaternary, however, communication between the Arctic and Atlantic was more or less interrupted by a bar between Greenland and Norway or Scotland; until this bar was submerged, glaciation was unable to develop over the British Isles.

In another respect the classical work of Penck and Brückner in the Alps fits the theory very closely, giving exactly the required sequence of four glacial periods and three interglacials, of which the second was known to be very long compared with the third, while the latter was exceedingly wet and warm. The theory is supported also by recent discoveries in tropical Africa of two great pluvial periods separated by a very dry interpluvial. Archæologically, the third interglacial is dated in Europe by the Acheulean, which is everywhere associated with a warm fauna. From the geological record, Dr. Simpson estimates that at the maximum of the solar radiation the 